\title{
DESCRIPTIONS AND PROCEDURES FOR INFORMED CONSENT IN EMERGENCY UNITS IN ALL HOSPITALS IN PADANG CITY
}

\author{
Rika Susanti \\ rikasusanti@med.unand.ac.id
}

Division of Forensic and Medicolegal, Faculty of Medicine, Universitas Andalas, Padang

\begin{abstract}
All medical treatments must be taken based on the patient's agreement. Patients in Emergency Unit can have a high risk of disability and even death. Many cases of patient prosecutions occur due to informed consent, either because the information is incomplete or because the doctor does not ask for written consent document. At present, there are still various formats of informed consent in several hospitals, and the procedures for informed consent are also different. This can be caused by different regulations that have been made by the hospital or because of the lack informations of the doctor's about informed consent.This was a descriptive study. The population is the sample in this study which are the Hospital in Padang City. Data was collected from interviews with doctors in the Emergency Units and taking the informed consent format at the Emergency Unit. The results showed that the percentage of hospital followed based on standard format was the Reksodiwiryo Hospital and Central BMC General Hospital with complete results of $100 \%$. Followed by Semen Padang Hospital and RSI. SitiRahmah with $97.7 \%$, YosSudarso Hospital 84.6\%, RSUD. Rasidin 35.6\%, RS. Aisyiyah 32.5\%, Hospital. Bhayangkara Hospital $29.8 \%$ and Hospital. Selaguri $16.7 \%$. The average hospital in the Padang City didnt not followed based on standard format from the Ministry of Health and Medical Councils Indonesia under consideration that they didn't know or have used the old format for years and are reluctant to replace it. There were some differences in formatting the informed consent of each hospital.
\end{abstract}

Keywords: Informed Consent, Emergency Unit

\section{Introduction}

Medical measures can only be done with the patient's consent. A patient has the right to know what medical actions are being done to him. ${ }^{1.2}$ Emergency unit is a facility for handling emergency patients. In medical emergencies, there were several main problems, namely the observation period / service time was relatively short, the clinical patients who could change suddenly, and high staff mobility. Actions in an emergency have a high risk for patients in the form of disability and even death. ${ }^{3.4}$

In an emergency or life-saving situation, noisneededinformedconsent.In the context of practice informed consentremains important, but should not be a barrier to life-saving actions. Provisions regarding informed consent in emergency cases are contained in Article 4 paragraph (1) of the Minister of Health Regulation Number 290 / Menkes / Per / III / 2008 concerning Medical Action Agreements stating that in an emergency to save patients' lives and / or prevent disability is not needed an agreement on medical action.

Many cases of patient demands occur due to informed consent, either because the information submitted is incomplete and not understood by the patient / guardian or because the doctor does not ask informed consent for writtenfor high-risk actions. ${ }^{5.6}$

The procedure for obtaining informed consent has been regulated in the medical action approval manual issued by the Indonesian Medical Council (KKI) in 2006. The manual describes all aspects related to the approval of medical action and the refusal of medical action. Starting from the parties involved, 
procedures, format, how to get approval, and so forth. The hospital should refer to the medical action approval manual issued by KKI in formatting and obtaining informed consent, so that the proof of agreement obtained has legal force.

At present there are still various formats of informed consent in several hospitals, and the procedure for informed consent is also still different between one hospital and another hospital. This can be caused by rules that have been made by the hospital or because of the doctor's understanding that is still lacking in informed consent. Based on the description above, the writer wants to examine the format and procedures for informed consent in the ED in hospitals in the padang city.

\section{LITERATURE REVIEW}

\section{Definition}

Informed is to give an explanation of all that relates to the patient's illness and what medical actions to be performed by the doctor as well as other things that need to be explained by the doctor for patient or family questions. Concentration is approval given to someone to do something. Thus informed consent is the agreement given by the patient to the doctor after being given an explanation. ${ }^{7}$

\section{Legal Basis}

Some of the legal bases of informed consent are:

1. Minister of Health Regulation of the Republic of Indonesia number 290 / Menkes / Per / III / 2008 concerning approval of medical actions.

2. Law number 29 of 2004 concerning Medical Practices

3. Law number 44 of 2009 concerning hospitals

4. Act number 36 of 2009 concerning Health

\section{Objectives}

In the relationship between implementers (doctors) and medical service users (patients), the implementation of informed consentaims: ${ }^{8}$

1. Protecting users legally medical (patient) action services from all medical actions carried out without his knowledge, as well as implementing acts of arbitrary medical treatment services, malpractice actions that conflict with patients' human rights and medical professional standards, and abuse of sophisticated tools that require high costs actually no need and no medical reasons.

2. Providing legal protection to the implementers of medical actions from patients' claims that are not fair, as well as the consequences of unexpected and negative medical actions, for example on "risk of treatment" which cannot be avoided even though the doctor has acted carefully and thoroughly and accordingly with medical professional standards.

\section{Form of consent (consent) and the party entitled to give consent}

There are two forms of agreement, namely: ${ }^{8}$

A. Expressed consent

Approval is given in written and oral form. Approval in carrying out invasive actions, both for diagnosis and therapy, such as endoscopy, surgery, chemotherapy and radiation. For mild cases, such as ultrasound, EKG or injection, consent can be given orally. 


\section{B. Implied consent}

Implied consent is permission given without being expressed, both written and oral. The permission from the patient is interpreted by the doctor by looking at a non-negativistic or antagonistic attitude. For example, when a patient comes to consult, in fact he has brought a positive attitude, namely that he already has the intention to give permission to the doctor to interview and examine it physically. This is what happens in all doctor's offices. All patients who come to consult, are considered to have given their permission. Such an attitude is not considered to violate theprocess informed consent, both in terms of legal and ethical law.

The higher the trust of a patient to the doctor, the more likely that his informed consentwill be given in the form of implied consent. But for large cases, especially those related to invasive actions that might affect quality of life, it is best to give written consent. ${ }^{8}$

According to Appelbaum, what is meant by invasive action is an action that uses a device inserted into the body, whereas according to Permenkes 290 in 2008, invasive action is all actions that can directly affect the integrity of the body's tissues.

Article 45 of Law No. 29 of 2004 concerning Medical Practice paragraph (5) states that "Every high-risk medical or dental action must be given with a written agreement signed by those entitled to give consent." Generally it is stated that examples of high-risk actions are invasive (certain) or surgical procedures that directly affect the integrity of body tissue. Written consent is needed in the following circumstances: ${ }^{9}$

1. When therapeutic measures are complex or involve significant risks or side effects.

2. If the medical action is not in the context of therapy.

3. If the medical action has a significant impact on the position of staff or patient's personal and social life.

4. If the action taken is part of a study.

Those who have the right to declare consent are:

1. Patients (if they are 18 years old or married).

2. Patients under the age of 18 are given by them according to the following rights: (1) biological mother / father, (2) siblings.

3. For those under the age of 18 years and do not have parents or parents unable to attend, they are given according to the following order of rights: (1) adoptive father / mother, (2) siblings, (3) landlady.

4. For adult patients with mental disorders, they are given in the order of rights as follows: (1) biological mother / father, (2) legal guardian, (3) siblings.

5. For adult patients who are under the custody (curatelle), given according to the order of rights as follows: (1) Guardian, (2) Curator.

6. For adult patients who are married / parents, given by them in the order of rights as follows: a. Husband / wife, b. Biological father / mother, c. Biological children, d. Siblings.

\section{Format and contents of informed consent}

Refer to the Medical Action Approval Manual issued by KKI in 2006, following the format and contents of the document providing information and approval for medical action. 
CONTOH FORMAT DOKUMENTASI PEMBERIAN INFORMASI

\begin{tabular}{|c|c|c|c|}
\hline \multicolumn{4}{|c|}{ DOKUMEN PEMBERIAN INFORMASI } \\
\hline \multicolumn{2}{|c|}{ Dokter Pelaksana Tindakan } & & \\
\hline \multicolumn{4}{|c|}{ Pemberi informasi } \\
\hline \multicolumn{4}{|c|}{ Penerima Informasi } \\
\hline & JENIS INFORMASI & ISI INFORMASI & TANDAI \\
\hline 1 & Diagnosis (WD \& DD) & & \\
\hline 2 & Dasar Diagnosis & & \\
\hline 3 & Tindakan Kedokteran & & \\
\hline 4 & Indikasi Tindakan & & \\
\hline 5 & Tata Cara & & \\
\hline 6 & Tujuan & & \\
\hline 7 & Risiko & & \\
\hline 8 & Komplikasi & & \\
\hline 9 & Prognosis & & \\
\hline 10 & Alternatif \& Risiko & & \\
\hline \multicolumn{3}{|c|}{$\begin{array}{l}\text { Dengan ini menyatakan bahwa saya telah menerangkan hal-hal di atas } \\
\text { secara benar dan jujur dan memberikan kesempatan untuk bertanya } \\
\text { dan/atau berdiskusi }\end{array}$} & \\
\hline \multicolumn{3}{|c|}{$\begin{array}{l}\text { Dengan ini menyatakan bahwa saya telah menerima informasi } \\
\text { sebagaimana di atas yang saya beri tanda/paraf di kolom kanannya, dan } \\
\text { telah memahaminya }\end{array}$} & \\
\hline
\end{tabular}

Figure 1. Example Format of Documentation in Giving Informations

CONTOH FORMAT PERSETUJUAN TINDAKAN KEDOKTERAN

\begin{tabular}{|c|c|c|c|}
\hline \multicolumn{4}{|c|}{ PEMEERIAN INFORMABI } \\
\hline \multirow{2}{*}{\multicolumn{4}{|c|}{ Dokter Felastana Thuskan }} \\
\hline \multicolumn{3}{|c|}{ Pember Intormasl } & \\
\hline \multicolumn{4}{|c|}{$\begin{array}{l}\text { Penerma Informas: / pembern } \\
\text { persefuluan. }\end{array}$} \\
\hline & JENIS INFORMABI & II INFOFMASII & TANDA (V) \\
\hline 1 & Disgnosis (WD \& DD) & & \\
\hline 2 & Dasar Dispnosia & & \\
\hline 3 & Thdaxan Kedoxteran & & \\
\hline 4 & Inakas: Tnoskan & & \\
\hline 5 & Tata Cara & & \\
\hline 6 & Tuluan & & \\
\hline 7 & Flako & & \\
\hline 8 & Kompilikasi & & \\
\hline 9 & Prognosia & & \\
\hline \multirow{2}{*}{10} & Antemsor \& Filg ko & & \\
\hline & Lain-Isin & & \\
\hline \multicolumn{3}{|c|}{ 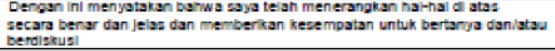 } & tandatangan \\
\hline \multicolumn{3}{|c|}{  } & tandatangan \\
\hline \multicolumn{4}{|c|}{ 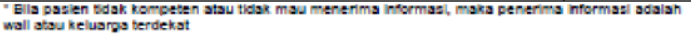 } \\
\hline \multicolumn{4}{|c|}{ PER3ETUJUAN TINDAKAN KEDOKTERAN } \\
\hline \multicolumn{3}{|c|}{ 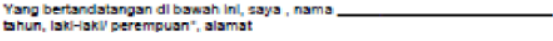 } & unur \\
\hline \multicolumn{4}{|c|}{ 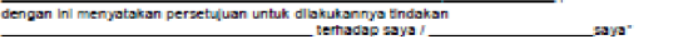 } \\
\hline \multicolumn{4}{|c|}{ 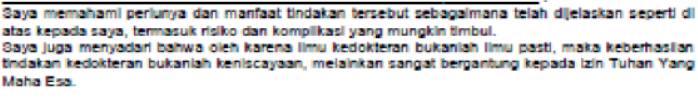 } \\
\hline \multicolumn{4}{|c|}{ Yang menyatsan : sast: } \\
\hline & $\longrightarrow$ & 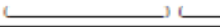 & \\
\hline
\end{tabular}

Figure 2. Example Format for Approval of Medical Measures 


\section{Procedure for informed consent}

Procedure for obtaining approval in medical action consists of providing information and obtaining approval.

\section{Providing information}

Informed consent does not have to be given in writing, in this case given orally still valid as informed consent, provided the patient is given a sufficient explanation in advance about the things that should be informed. Informed consent can also be considered to exist, implied by the patient's movements, or believed by the doctor (implied consent). ${ }^{10}$

For every action is a high risk, there must be a informed consent written(Expressed consent). The obligation to provide this information cannot be delegated (non-delegable duty), for example to nurses. This is because the responsible person is the doctor himself. The thing that should not be done is that in providing information may not be deceptive (fraud), pressing (force) or creating fear (fear), because these three things will make the agreement given to be a legal flaw. ${ }^{11}$

Things - things that need to be informed to patients or their families include: ${ }^{12}$

1. Reasons for the need for medical

2. action The nature of the medical action, namely an experiment or not an experiment.

3. The goals of medic actions, namely diagnostic, therapeutic, promotive, rehabilitative.

4. Procedures for medical action

5. Risks and complications that may occur

6. There are still alternative or no medical actions

7. Prognosis of actions taken

8. Estimated payment of

\section{Giving Approval}

All medical actions to be performed on the patient must be approved in writing or verbally. Approval was given after the patient received the necessary explanation about the need for medical action to be performed. ${ }^{5}$

The thing to note is that those who are entitled to give consent are adults (over 18 years old or married) and mentally healthy. For patients under the age of 18, and patients with mental disorders who sign up are the closest parents / guardians / families or landlords. For patients who are unconscious, or unconscious and not accompanied by their closest family and medically in an emergency that requires immediate medical action, no approval from anyone is needed. ${ }^{5}$

Informed consent is not absolutely made by the patient in question in the case - as follows: ${ }^{8}$

1. Patient minors / minors and unmarried,

2. age is already very advanced and senile

3. Disturbed her soul for a disease

4. patient is unconscious

ER

Emergency Room (ER) hospital is one part of the hospital that provides early treatment for patients suffering from illness and injury, which can threaten their survival. ${ }^{4}$ The Ministry of Health has issued a policy regarding the Hospital IGD Standard as stated in the Minister of Health Decree No. 856 / Menkes / SK / IX / 2009 to regulate the standardization of emergency services in hospitals. The IGD also provides a means of acceptance for the management of patients in disaster situations, this is part of its role in assisting the disaster situation that occurs in each region. ${ }^{13}$

Emergency is a condition where the patient needs an immediate medical examination, if not done it will be fatal for the sufferer. ${ }^{14}$ 
Medical action is an effort filled with uncertainty, and the results cannot be calculated mathematically. Almost all medical actions have risks, which can occur and can also not occur. ${ }^{15}$

\section{Legislation related to emergency services.}

Legislation related to emergency services are:

a. Law No. 36 of 2009 concerning Health ${ }^{16}$

b. Regulation of the Minister of Health of the Republic of Indonesia No. 290 / MENKES / PER / III / 2008 concerning Approval of Medical Action ${ }^{17}$

c. Law No.29 of 2004 concerning Medical Practice ${ }^{18}$

In the event of an emergency to save the lives of patients and / or prevent disability approval for medical action, this decided by medical personnel and must be recorded in the medical record, an explanation must be given as soon as possible to the patient after the patient is aware or to the closest family. In special situations where there is an act of stopping / delaying life assistance in a patient, the family must get the closest consent from the patient in writing, and this must be preceded by a doctor's explanation. Another situation where medical action must be carried out in accordance with government programs, where the medical action is for the benefit of many people, then the approval of medical action is not needed. ${ }^{17}$

In pediatric patients, medical treatment can still be performed by a doctor even without parental consent on condition:

a. Medical measures to be taken must be therapeutic, not experimental medical measures.

b. Without this medical action, the child will die, and the

c. medical action provides hope or opportunity for the child to live a normal, healthy and beneficial life.

\section{METHODS}

This study is a descriptive study that illustrates the format and procedures for informed consent in Emergency Services in all Padang City Hospitals. The population is the sample in this study, namely the Hospital in the Padang city. Data was collected from interviews with doctors in the Emergency unit and taking the informed consent format at the Hospital emergency room. Inclusion criteria are hospitals that have been operating for more than 1 month, have informed consent and doctors guard the emergency department who have practiced in the hospital for more than one month. The exclusion criteria were hospitals that refused to be the study sample.

\section{Results}

Format of informed consent in hospitals in Padang City. Total sample was nine hospitals in the Padang City, namely the hospital. Dr. Reksodiwiryo, RS. YosSudarso, RSU. Central Bunda Medical Center (BMC), Hospital. AisyiahMuhammadiyah, RS. West Sumatra Regional Bhayangkara, Hospital. Selaguri, Semen Padang Hospital, RSUD. Rasidin Padang, and Hospital. Islam SitiRahmah. The format of informed consent in each hospital in the padang city, is different.Different forms of death certificates in each hospital were caused because the informed consent format was adjusted to the regular procedures of each hospital.

There are differences in the number of informed consent sheets for each hospital in the padang city. At the hospital. YosSudarso, RST. Reksodiwiryo, Semen Padang Hospital, Hospital. Selaguri, Hospital. PolriBhayangkara, RS. Aisyiyah, RSU. BMC has 2 pages that separate between informed consent approval and rejection. Whereas at the RSUD. Rasidin and RSI. SitiRahmah only consisted of 1 informed consent sheet which included approval and rejection in accordance with the standard format. 
Data on conformity of the informed consent format was carried out by comparing the requested consent format from each hospital with the standard format from the Ministry of Health. Data from the comparison of the informed consent format are obtained by calculating the number of parts contained in the informed consent format of each hospital divided by the number of sections in the standard format multiplied by $100 \%$. Using this method, the results of the percentage data of the informed consent format in each hospital were obtained. There are two parts in the standard informed consent format, namely the approval section and the rejection section. Conformity of the informed consent format approval section used by the Hospital Dr. Reksodiwiryo is $100 \%$, RS. YosSudarso $88.4 \%$, RSUC. BMC 100\%, RS. Aisyiyah M. 41.9\%, Hospital. West Sumatra Regional Police Bhayangkara 32.6\%, Hospital. Selaguri 25.6\%, Semen Padang Hospital 95.4\%, RSUD. Rasidin Padang 32.6\% and 95.4\% in hospitals. Islam SitiRahmah. The comparison table of the informed consent format for the approval of each hospital in the padang city with the standard format of the Ministry of Health is in the appendix.

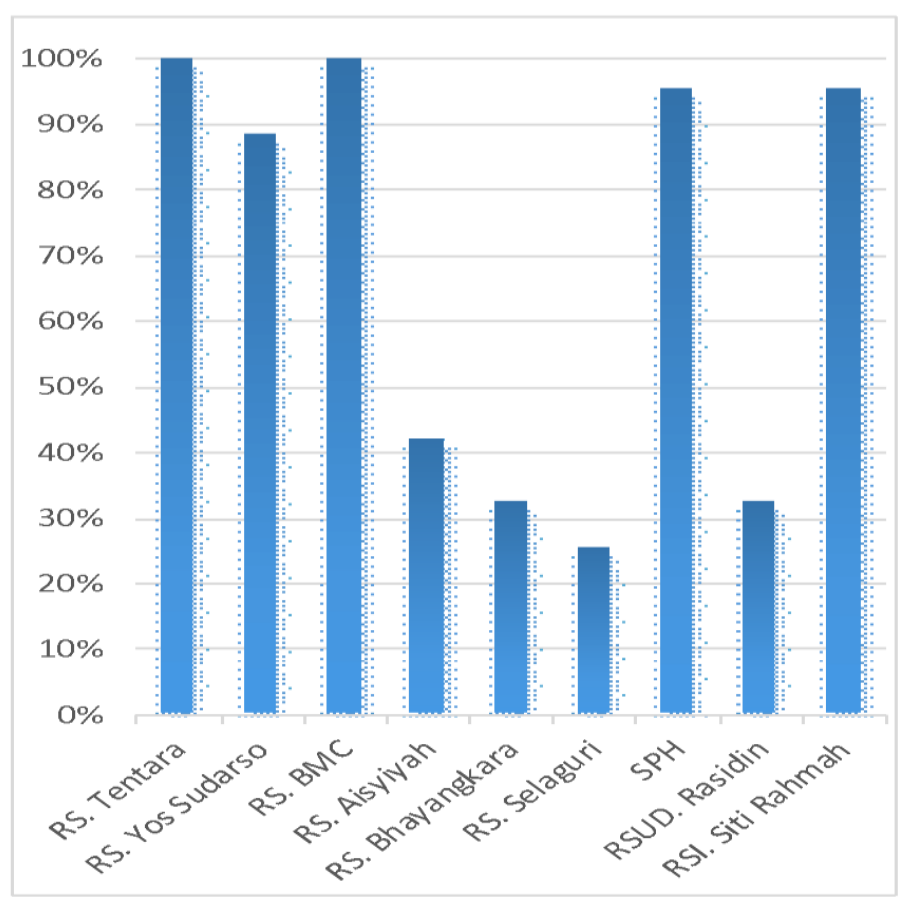

Figure 3. Percentage of conformity Approval of Informed Consent

Conformity to informed consent in the rejection section is different for each hospital. This is influenced by the informed consent format of the approval section. Usually, if the format of the agreement is different then the format for rejection is different. However, there are some hospitals where the format of approval and rejection is made separately, so that more conformity to the rejection format approaches the standard format compared to the format of the agreement. Reksodiwiryo Army Hospital gets a 100\% suitability percentage, RS. YosSudarso 80.8\%, Hospital. AIsyiyah 23.1\%, Semen Padang Hospital 100\%, RSU. BMC 100\%, RS. Bhayangkara National Police 26.9\%, Hospital. Selaguri 7.7\%, RSUD. Rasidin $38.5 \%$ and RSI. SitiRahmah $100 \%$. 


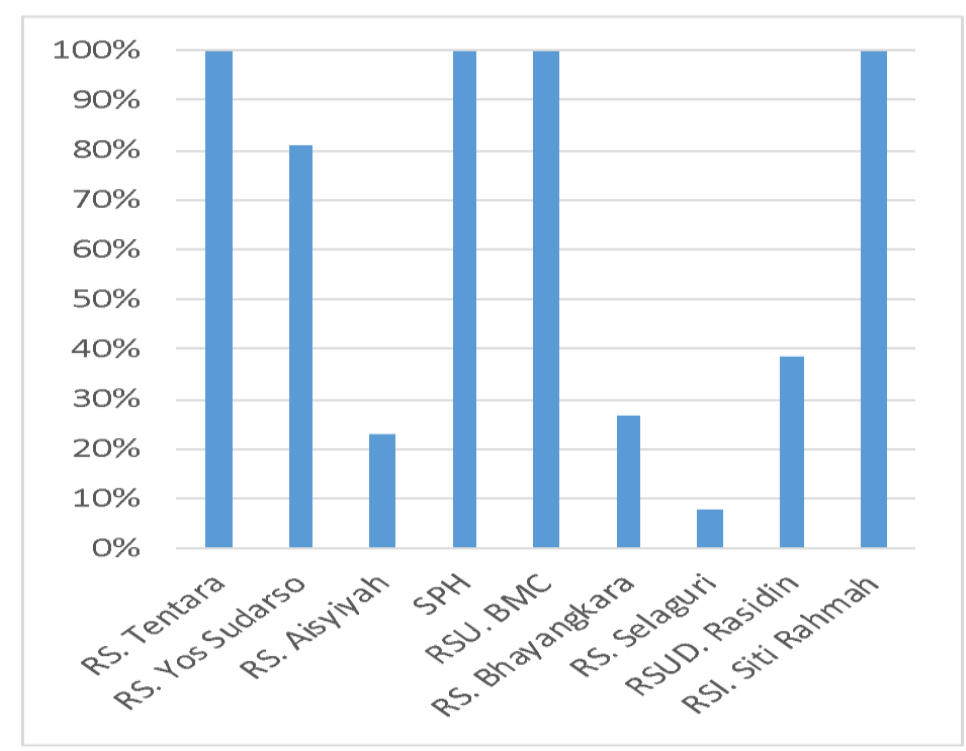

Figure 4. Graph of Percentage of Format for Rejection Informed Consent

\section{Overview of Expenditures Informed Consent at Hospital in Padang The}

Number of hospitals sampled was nine hospitals in the padang city, namely RS. Dr. Reksodiwiryo, RS. YosSudarso, RSU. Central Bunda Medical Center (BMC), Hospital. AisyiahMuhammadiyah, RS. West Sumatra Regional Police Bhayangkara, Hospital. Selaguri, Hospital. PT Semen Padang, RSUD. Rasidin Padang and Hospital. Islam SitiRahmah. In the interview process of this study, the studyers interviewed each of the two doctors who guarded the Emergency Unit (ER) or Emergency Room (IGD) in nine hospitals in Padang City, so that eighteen interviews were obtained. In the interview, the studyer interviewed the doctor on duty one by one, so that the data obtained was a description of the knowledge of each doctor, keeping in mind about the informed consent in each hospital.

Each hospital has an average informed consent format that has been used in its service. In the interview, there were $94.40 \%$ or seventeen physicians who responded to the informed consent of the ER / ED and $5.60 \%$ or one guard doctor said no. In this case, it is illustrated in the diagram below.

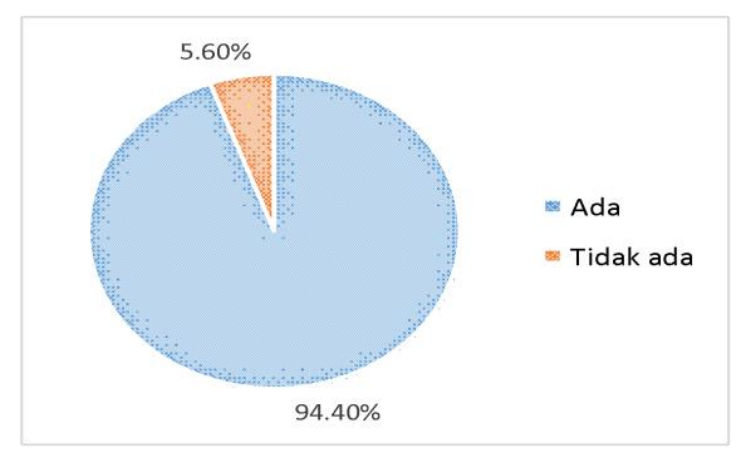

Figure 5. Diagram knowledge about procurement of IC in the ER / ED in each hospital. 
Knowledge of the existence of a standard format for informed consent in Indonesia, out of the eighteen guardians interviewed, $61.11 \%$ or eleven doctors were aware of the format and $38.88 \%$ or seven doctors did not know it. More details can be seen in the diagram below.

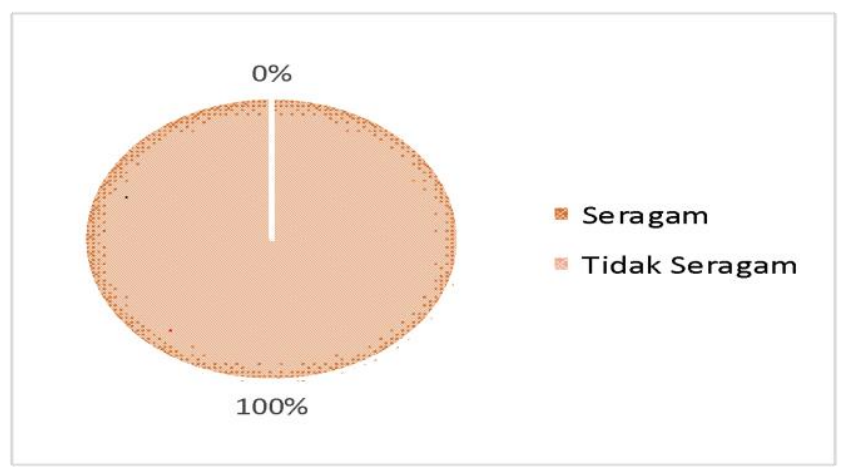

Figure 6. Diagram of knowledge about Uniformity IC format in all parts of the hospital.

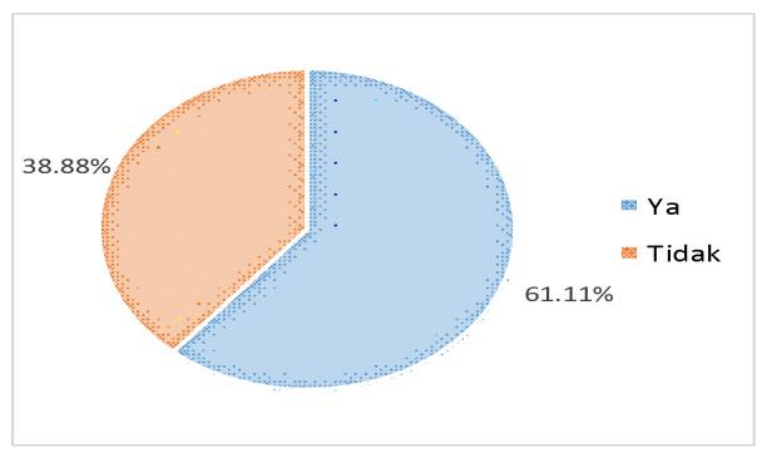

Figure 7. Diagram of knowledge about IC standard formats in Indonesia

Of the nine hospitals, there were $94.40 \%$ or seventeen doctors who made all written informed consent preceded by oral to patients and their families and $5.60 \%$ or one doctor on duty did not make written informed consent or only on invasive measures. This can be clearly illustrated in the diagram below.

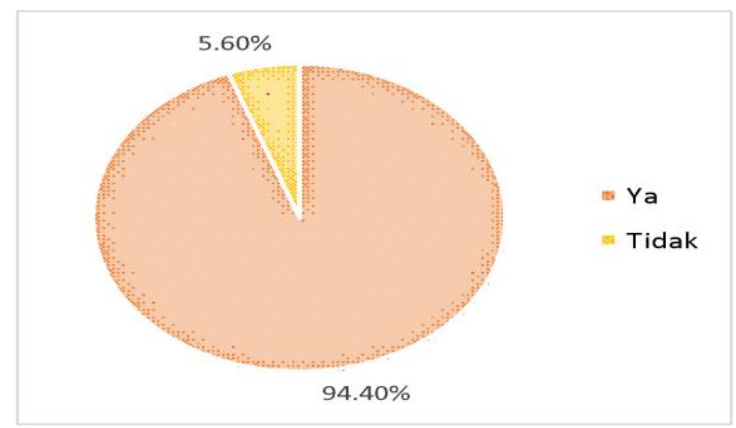

Figure 8. Diagram of knowledge about IC making in medical actions in emergency services. 
The format that has been used by hospitals between one and five years is $22.22 \%$ or four hospitals, six to ten years $33.33 \%$ or six hospitals and more than ten years $44.44 \%$ or eight hospitals. This has been illustrated in the diagram below.

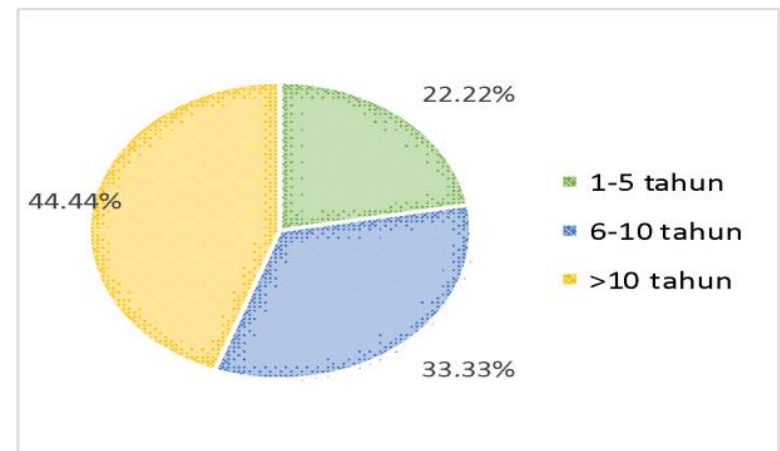

Figure 9. Diagram about the lenght of the IC format is used in hospitals.

Of the eighteen doctors on duty, there were $83.33 \%$ or fifteen doctors stating that the obligation to provide information was with the doctor who would take the action, $5.55 \%$ or two doctors stated that they could be delegated to other medical officers and $11.11 \%$ or one doctor states may delegate these obligations to other doctors.

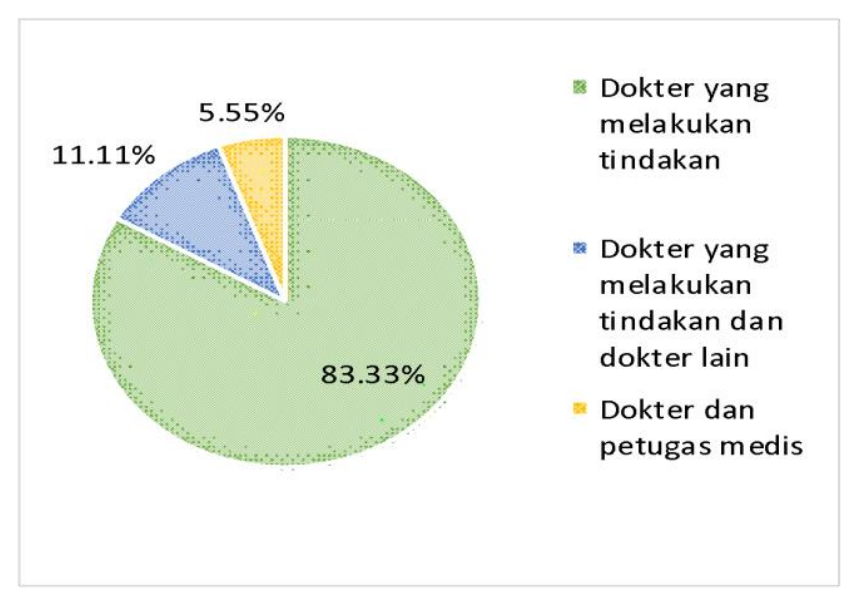

Figure 10. Diagram of giving information to patients and families of patients.

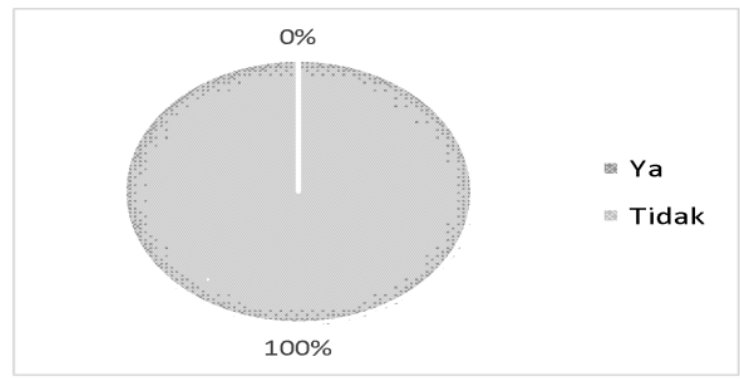

Figure 11. DiagramIC signing after giving information. 
When the patient is conscious, there are $38.88 \%$ or seven doctors stating that the patient must sign an informed consent, $38.88 \%$ or seven doctors state that the family signed an informed consent and $22.22 \%$ or four doctors on duty allow patients / families to signed an informed consent. More details can be seen in the diagram below.

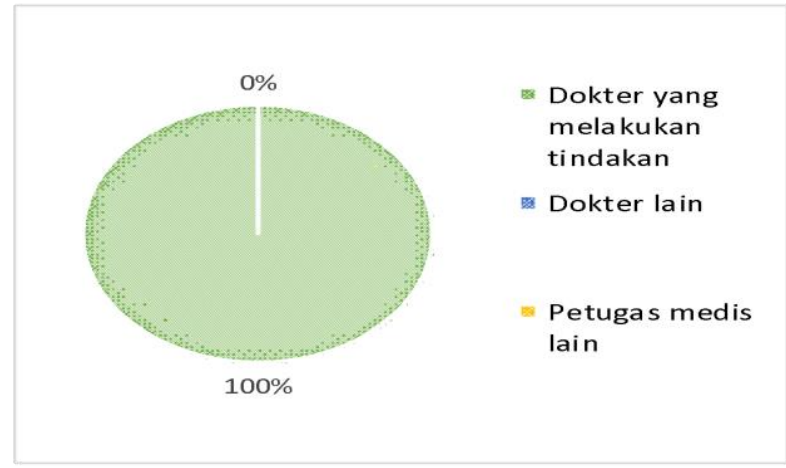

Figure 12. Diagram of the patient's party who signed an informed consent.

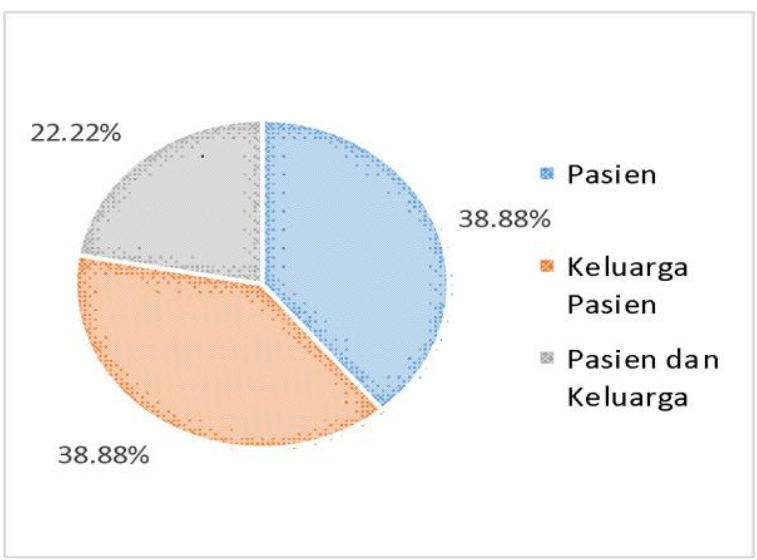

Figure 13. Diagram of signing the IC when the patient is conscious.

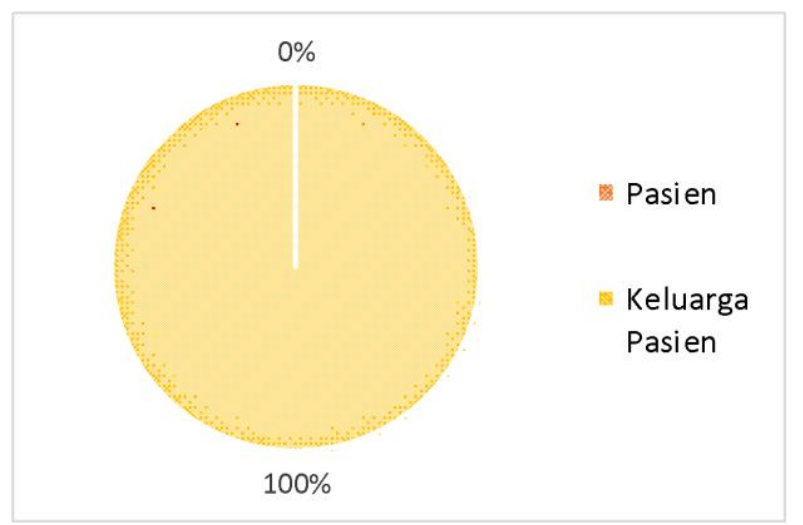

Figure 14. DiagramIC approval when the patient is unconscious. 


\section{Discussion}

Format of Applicable Informed Consent to Hospitals in Padang. According to the informed consent format established by the Ministry of Health and ICM, there is only one sheet of reciprocity which includes documentation of the provision of information, approval of medical actions and refusal of medical action. In this format, there are important points in making informed consent. In the information documentation section, there must be the name of the acting doctor, the name of the information provider, the name of the recipient of the information. Then, in the type of information, there must be a diagnosis point (WD / DD), the basis of the diagnosis, medical action, medical indications, procedures, goals, complications, prognosis, and alternatives and risks. After that, at the end of the information documentation there must be a statement and signature of the doctor stating that he has provided information and the opportunity to ask questions, as well as the statement and signature of the patient stating he has been given information in accordance with the check he marked.

In the medical action approval section, like an informed consent format, there must be the name of the acting doctor, the name of the information provider / approver. In the type of information, there is a diagnosis (WD / DD), basic diagnosis, medical action, medical indications, procedures, goals, complications, prognosis, as well as alternatives and risks. The final section, there is a statement and signature of the doctor stating that he has provided information and provided an opportunity to ask questions, statement and signature of the patient stating that he has been given information in accordance with the check he marked, signed statement for approval of medical action (name, age, gender, address), what action is taken and for whom (name, age, gender, address), the sentence I understand is necessary and the benefits of the above actions, including risks and complications that may arise, the sentence that medical science is not an exact science, then success medical action is not a necessity but it is very dependent on the permission of the Almighty God, the date and time of giving approval and a signature stating on the left side and the signature of two witnesses on the right side.

While the rejection part of the action, in the standard format, there must be points, namely the name of the acting doctor, the information provider, and the recipient of the information / approver. In the type of information, there is a check in the form of a diagnosis (WD / DD), the basis of the diagnosis, medical action, indications of action, procedures, goals, complications, prognosis and alternatives and risks. After that, at the end there is a statement and signature points from the doctor stating that he has provided information and the opportunity to ask questions, statements and signatures of the patient stating he has been given information in accordance with the check he marked, signed statement for approval of medical action (name, age , gender, address), what action is taken and for whom (name, age, gender, address), the sentence I understand is necessary and the benefits of the above actions, including risks and complications that may arise, the sentence that medical science is not science surely, the success of medical action is not inevitable but depends on the permission of God Almighty, the date and time of giving consent and the signature stating on the left side and the signatures of two witnesses on the right side.

When viewed from the standard format issued by the Ministry of Health and KKI, it can be concluded in this study, that there are still a number of hospitals in Padang City that have not converted the informed consent format in the emergency room into their standard format. Obtained the conformity of the informed consent format approval section used by the Hospital. Dr. Reksodiwiryo is $100 \%$, RS. YosSudarso 88.4\%, RSUC. BMC 100\%, RS. Aisyiyah M. 41.9\%, Hospital. West Sumatra Regional Police Bhayangkara 32.6\%, Hospital. Selaguri 25.6\%, Semen Padang Hospital 95.4\%, RSUD. Rasidin Padang $32.6 \%$ and $95.4 \%$ in hospitals. Islam SitiRahmah. In the rejection section of the action, the Reksodiwiryo Army Hospital received a 100\% suitability percentage, RS. YosSudarso 80.8\%, Hospital. Aisyiyah 23.1\%, Semen Padang Hospital 100\%, RSU. BMC 100\%, RS. Bhayangkara National Police 26.9\%, Hospital. Selaguri $7.7 \%$, RSUD. Rasidin $38.5 \%$ and RSI. SitiRahmah $100 \%$. 
The percentage results that correspond to the standard format are the Reksodiwiryo Army Hospital and Central BMC General Hospital with perfect results of $100 \%$. Followed by Semen Padang Hospital and RSI. SitiRahmah with 97.7\%, YosSudarso Hospital 84.6\%, RSUD. Rasidin 35.6\%, RS. Aisyiyah 32.5\%, Hospital. Bhayangkara Police 29.8\% and Hospital. Selaguri with $16.7 \%$.

The average hospital in the padang city, does not use the standard format from the Ministry of Health and Indonesian Migrant Workers on the grounds that they do not know or have used the old format for years and are reluctant or there is no order to replace it. This should be a concern for Health Agencies in Padang City, especially those responsible for disseminating information regarding standard formats, especially informed consent so that uniformity can occur, so that recording and accountability of health workers in the eyes of the law becomes stronger and better in terms of medical action to patients.

\section{Procedure for Informed Consent in Hospitals in Padang City}

There are some differences in the preparation of the informed consent format of each hospital. This proves that there is an information gap between hospitals that have made the informed consent format in accordance with the applicable provisions, some are still in the development and improvement phase in accordance with the provisions and there are those who have used the format for years without following the conditions.

Each hospital has an average informed consent format that has been used in its service. In the interview, there were $94.40 \%$ or seventeen physicians who responded to the informed consent of the ER / ED and $5.60 \%$ or one doctor on duty said no.

\section{Conclusion}

The format of informed consent in each hospital must be uniform from the emergency department, care inpatient, poly clinic services to surgical services. The statement has been proven in the results of interview studyers. Of the eighteen guardians interviewed, all of them answered the uniformity of the informed consent format in the hospital. However, there are a number of hospitals that do not use the standard format or only list the informed consent in the polyclinic status or control card. Knowledge of the existence of a standard format for informed consent in Indonesia, out of the eighteen guardians interviewed, $61.11 \%$ or eleven doctors were aware of the format and $38.88 \%$ or seven doctors did not know it.

In emergency services, there are differences in doctor's knowledge in making informed consent in medical action. There are several attending physicians who just made a statement of informed consent to the actions that are considered invasive, such as suturing wounds(hecting),circumcision, injections of antibiotics and other sebagianya, while the actions of non-invasive not made informed consent, only made orally to patients and families. Of the nine hospitals, there were $94.40 \%$ or seventeen doctors who made all written informed consent preceded by oral to patients and their families and $5.60 \%$ or one doctor on duty did not make written informed consent or only on invasive measures .

The informed consent format used in each hospital turned out to have different ages. The studyer divides the format age scale used or the length of the format used in services between one to five years, six to ten years, and more than ten years. The format that has been used by hospitals between one and five years is $22.22 \%$ or four hospitals, six to ten years $33.33 \%$ or six hospitals and more than ten years $44.44 \%$ or eight hospitals. However, there are several hospitals which state that in 2016 the informed consent format is in the stage of repairing and approving the hospital directors to lead to a standard format, so that the informed consent format must have been used for a long time, with the emergence of new formats. being a criterion of one to five years. 
Before making written informed consent, it is required that those who take action notify all information related to the action, both in terms of profit, loss, cost, prognosis and side effects. It is best to give information to patients and families who want to take action is the doctor who takes action. However, there are several hospitals that can delegate the task of providing information to other more primary doctors, such as from specialist doctors to general practitioners who are on duty in emergency services or other medical officers. Some hospitals also free up the obligation to provide information to patients and their families to doctors or other medical officers. Of the eighteen doctors on duty, there were $83.33 \%$ or fifteen doctors stating that the obligation to provide information was with the doctor who would take the action, $5.55 \%$ or two doctors stated that they could be delegated to other medical officers and $11.11 \%$ or one doctor states may delegate these obligations to other doctors. After giving information to patients and their families, then written informed consent is made about the important things in these actions which have been stated in the points of the informed consent format. All doctors on duty at each hospital will issue an informed consent letter after being given information first.

Right at the bottom of the informed consent letter there is a column that must be signed by the doctor and the patient, both the patient himself and the patient's family. In the case of signing the informed consent from the doctor's side, all physicians in the emergency services section stated that only the doctor who did the action could sign the letter. While for the patient's consent column or the patient's family there are differences. When the patient is conscious, there are $38.88 \%$ or seven doctors stating that the patient must sign an informed consent, $38.88 \%$ or seven doctors state that the family signed an informed consent and $22.22 \%$ or four doctors on duty allow patients / families to signed an informed consent.

\section{References}

1. Afiani, N., (2012). Informed consent di Instalasi Rawat Darurat. Diakses pada 20 April 2016.

2. Inayati, I.N., (2011). Aspek hukum rekam medis dan informed consent. Diakses pada 20 April 2016.

3. Triwibowo, C., (2010). Informed consent dalam kondisi kegawatdaruratan. Diakses pada 20 April 2016.

4. Herkutanto, (2007). Aspek mediko legal pelayanan gawat darurat. MajKedoktIndon. 57(2): 37-40.

5. Toto S.S., (2015). Implementasi peraturan menteri kesehatan nomor 290 tahun 2008 tentang persetujuan tindakan kedokteran di Instalasi Gawat Darurat (IGD) Rumah Sakit Umum Daerah (RSUD) kabupatenWakatobi Provinsi Sulawesi Tenggara. Yogyakarta :Universitas Gadjah Mada. Diakses pada 20 April 2016.

6. Pratiwi, B. S., (2015). Referat forensik. Diakses pada 20 April 2016. http://documents.tips/documents/referat-forensik-566840516b363.html

7. Hanafiah dan A.Amir. Etika kedokteran dan Hukum Kesehatan. Jakarta: EGC. hal: 68.

8. Guwandi, J. Informed Consent and Informed Refusal, $4^{\text {th }}$ edition.2006. Balai penerbit Fakultas Kedokteran Universitas Indonesia, Jakarta. hal 17

9. Konsil Kedokteran Indonesia. 2006. Manual Persetujuan Tindakan Kedokteran. Jakarta :Penerbit Konsil Kedokteran Indonesia. 
10. BPJS kesehatan. 2014. Kumpulan panduan praktis Layanan BPJS Kesehatan dan Peraturan Pelaksanaannyar $\quad$ Diakses $\quad 20 \quad$ pada $\quad 2016$. http://bpjskesehatan.go.id/bpjs/index.php/arsip/categories/OQ/manlak-jkn-bpjs-kesehatan

11. Sofwan, Dahlan. Hukum Kesehatan Rambu-rambu Bagi Profesi Dokter Edisi 3. 2005. Badan Penerbit Universitas Diponegoro: Semarang. hal 39 - 49

12. O’Neil. Some Limits of Informed Consent. J Med. Ethics. 2003; hal 29.

13. Direktorat Jenderal Pelayanan Medik Departemen Kesehatan. 2010. Akreditasi Pelayanan Gawat Darurat. Diakses pada 20 april 2016

14. Kamus Saku Kedokteran DORLAN. Jakarta : EGC, 1998

15. Herkutanto. Aspek Medikolegal Pelayanan Gawat Darurat. Majalah Kedokteran Indonesia, Volum: 57, Nomor: 2, Pebruari 2007.

16. Republik Indonesia. Undang - undang nomor 36 tahun 2009 tentang Kesehatan

17. Wila CH, Supriadi. 2008. Persetujuan Tindakan Medis. Bandung; Unika Parahyangan.

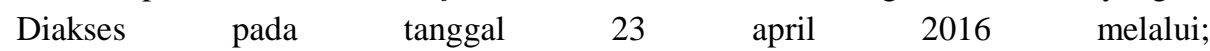
https://hukumkes.wordpress.com/2008/03/15/persetujuan-tindakan-medik/

18. Holder AR. Emergency room liability. JAMA 1972;220:5. 